\title{
Dryland Sustainable Livelihoods: Role of Clan and Customary Laws in West Timor, Indonesia
}

\author{
Yenny Tjoe, Griffith University, Australia
}

\begin{abstract}
Subsistence farming is one of the essential features of dryland regions to support people in coping with drought and rainfall variability. This paper examines the livelihoods of Atoin Meto, a tribal community that practices subsistence corn growing in dryland West Timor. It discusses the role of clan system and customary laws in the livelihoods of this tribal people. This study finds that the role of the Meto clan system and customary laws is twofold: it has contributed to reducing livelihood vulnerability in the region via the management of community forest resources and maintenance of members' rights to access farmland and natural resources. On the other hand, it also allows opportunity for the misuse of power by official village heads and hinders the process of development. Qualitative data were collected through group interviews, in-depth key informant interviews, and participant observation. This finding implies that, for this tribe to increase its capacity for sustainable rural development in dryland regions, future development policy for this region needs to find ways and means to improve local governance and replace corrupt village officials."
\end{abstract}

Keywords: Sustainable Livelihoods, Clan Belief, Subsistence, Village Head, Drylands, Meto People

\section{Background To The Study}

$\mathrm{W}$

est Timor is a semi-arid island, located in East Nusa Tenggara (NTT), the fourth poorest province of Indonesia. The regional economy relies mainly on agricultural production (nearly 35\% of NTT Regional-GDP in 2013) (NTT in Figures [Badan Pusat Statistik NTT (Bureau Statistics-BPS NTT] 2014). About $61 \%$ of its working population in 2013 made a living from agriculture (Gross Regional Domestic Product by Industrial Origin, 2004-2013 [BPS NTT 2015). Incidents of adverse weather have increased in recent years, such as long droughts, extreme rainfall and landslides, which escalated the region's poverty issue to the extent where crop failure, clean water and food crises occurred in almost all districts (Muslimatun and Fanggidae 2009; Badan Nasional Penanggulangan Bencana (National Bureau for Disaster Management)-BNPB 2009). Over the past decade, NTT has received increasing assistance from both government and non-government organizations, but many large-scale development projects had a negative impact on rural livelihoods (Tjoe 2013). Since 2009, economic development through natural resource exploration projects ${ }^{1}$ accelerated and the venues of these projects often overlapped with the habitat of the traditionally subsistence-based communities (Eki 2010; Kotta 2010; Yohanis 2010).

Subsistence farming is commonly found in poor districts of NTT where people grow corn or raise animals for domestic consumption (Barlow and Gondowarsito 2007). Atoin Meto (or the People of Dryland) is a major tribe in rural West Timor which performs subsistence farming to sustain livelihood. They account for two thirds of the total population in West Timor Island (Fox 1999). Given the potential impact of climate change on dryland ecosystems, it is essential that the

\footnotetext{
${ }^{1}$ Today, nearly $65 \%$ of NTT forest area is in a critical condition (NTT Provincial Government 2012). Economic development through natural resource exploration projects has accelerated following the passing of laws on exploration permits and production: Law No.4/ 2009 (Exploration Permits and Production), Ministry of Energy and Mineral Resources Regulation No. 28/ 2009 (Effectuation of Mining and Coal services), Government Regulation No. 22/ 2010 (Permitted Mining Areas), and Government Regulation No. 23/ 2010 (Operation of Mineral and Coal Production). For Manganese alone, nearly 200 permits were on the waitlist to explore the resources in Kupang district. In 2010, at least 194 permits were granted (including 54 in Kupang regency and 8 in Timor Tengah Selatan regency).
} 
government facilitate economic development in West Timor to sustain rural livelihoods. The aim of this paper is to analyze the current livelihood practice of the Meto People to provide recommendations for developing suitable poverty reduction agenda for dryland areas. Through group interviews, in-depth key informant interviews and participant observations, this study identifies three serious deficiencies in local governance which contributed to the poor livelihood conditions in the Meto People: (1) poor accountability in village government; (2) diminishing authority of customary laws; and (3) lack of educational competency in the community elders to admonish the village head for his poorer administration or to take legal action.

The next section of the paper reviews literature on sustainable rural livelihoods concepts and challenges. The study area and research method are discussed in the third section. Findings and discussions are presented in the fourth section. The fifth section provides recommendations and the conclusion of the paper.

\section{Sustainable Rural Livelihoods: Perspectives on Poverty and Development in Drylands}

\section{Challenges in Dryland Regions}

Drylands are regions where the amount of moisture losses through evapotranspiration is greater than the amount of rainwater falling on land surface (UNEP 1992). Dryland inhabitants throughout the world include nomadic and semi-nomadic pastoral groups, transhumant people, and sedentary farmers (FAO 2008); most of them live at basic subsistence level (FAO 2004). The main concern in dryland regions is whether the soil's natural resource base has the capacity to feed its increasing population (FAO 2008). Dryland farmers, in particular, pursue subsistence goals through small-scale agricultural production, often combined with additional incomes from non-agricultural sources (Hunt 1991). With multi-dimensional strategies in soil management and livelihood survival (Mortimore and Adams 1999; Kalame et al. 2010), their risk management is often self-relying rather than dependent on external institutions (Collinson 2000).

Early literature hypothesized a 'downward spiral' relationship between rural poverty and environmental degradation (Cleaver and Schreiber 1994), arguing that resource exploitation may be accelerated as food chains are endangered by population pressure or environmental changes. However, in more recent studies such as Scherr (2000) and Popovski and Mundy (2012), this hypothesis is countered. These studies argue that rural communities have considerable capacity to adapt to environmental stresses by employing a wide variety of coping mechanisms. Interestingly, other studies show that soil degradations in drylands may have been worsened through bad taxation and pricing policies on agricultural input and output (Barbier 2000), as well as weak credit markets and segmented labour markets (de Janvry, Fafchamps and Sadoulet 1991; Gisladottir and Stocking 2005). This indicates that land degradation in drylands is not solely due to the land use activities of the local inhabitants.

\section{Development Paradigms - From Growth-with-Modernization to Sustainable Livelihoods}

Since World War II, economic growth has become the principle criteria for national prosperity. In the 1960s, the era of 'growth-with-modernization' measured development by the average per capita output (Mitchell, Ingco and Duncan 1997). In the 1970s, the 'basic needs' approach was re-emphasized ${ }^{2}$ (Overseas Development Institute [ODI] 1978), calling all nations to include the improvement of the skills and productivity of the poor in their development agenda by ensuring the basic human needs of the poor (International Labour Organization [ILO] 1976). The five core

\footnotetext{
2 It is claimed that concern over the condition of the poor and expressions such as 'basic needs' have existed for thousands of years (ODI 1978).
} 
'basic needs' include nutrition, education, health, shelter, and water and sanitation (Streeten 1984). Also, in the same period, the 'growth-with-equity' paradigm emerged and stressed that the development of a nation was determined by its income distribution, employment, and nutrition of the people (Mitchell, Ingco and Duncan 1997). However, throughout this development paradigm, there were a number of unsettled questions, particularly on how to ensure human resource development for the poor (Streeten and Burki 1978; Streeten 1984). Streeten and Burki (1978, p. 412) point out three main problems that the development policy at the time ${ }^{3}$ failed to notice. Firstly, the improved skills and productivity of the poor led to higher wages and thus increased their incomes in the short-run, but in the long-run their real income declined because of the higher prices of products they purchased in the market. Secondly, the poor were unable to access or improve all basic needs by themselves, but there was insufficient provision of social services in place to help the poor improve their situation. Lastly, the ultimate objective of the basic-needs approach to development should be to ensure that the poor have opportunities to develop their full potential.

In the 1990s, 'responsible well-being' as an agenda for development emerged. The development paradigm shifted to the bottom-up approach and embraced the concept of Sustainable Rural Livelihood. Development policy which regarded economic growth (and income) as an end is criticized for ignoring the other realities ${ }^{4}$ of the poor (Chambers 1995). In addition, other studies found that the top-down approach tended to disrupt local unique knowledge in the problem solving process rather than actually sustaining the rural income. For example, Chambers, Pacey and Thrupp (1989) find that a monocrop farming system in resourcepoor regions of Asia did not necessarily help raise incomes. Since this period, the concept of 'livelihood' (rather than employment in jobs) was proposed as a new approach to encapsulate the realities of the poor.

\section{Rural Development and Subsistence-based Community in Developing Countries}

In the aftermath of WWII, rural development to eradicate poverty has focused mainly on improving the incomes of rural people. This is manifested in programs such as transforming traditional or subsistence agriculture into large-scale modern agriculture (Johnston and Mellor 1961; Schultz 1964; Mellor 1966), and introducing rational and productive use of resources for small-scale farmers (Lee and Goodland 1986). Rural poverty in developing countries is commonly portrayed as low agricultural productivity with the farmers resisting adopting agricultural insurance, new technology or land investment (Morduch 1994; Banerjee 2000; Duflo 2006).

However, rural poverty is more than simply the problems of agricultural productivity. Griffin and Khan (1978) argue that issues of inequality contribute equally to rural poverty. The cycle of inequality continues in rural areas, dis-incentivizing people to innovate, causing resentment and restraining initiative and creativity, thus allowing the small privileged group to continue capturing the surplus of economic growth (Griffin and Khan 1978, p. 298). Thus, to understand rural poverty, issues such as power and politics which shape inequality and suppression in rural areas should not be ignored (Scoones 2009).

In addition, there are various types of livelihoods in rural regions, and households choose one type over the others for, not only economic needs, but also cultural reasons. One example is the practice of subsistence farming by rural households. By definition, 'subsistence' refers to a way of life that is portrayed by low living standards, less productive techniques, less input of

\footnotetext{
${ }^{3}$ ILO focused on employment-oriented strategy and World Bank proposed 'Redistribution with Growth'.

${ }^{4}$ Chambers (1995) also criticizes how development professionals have been seeking, experiencing and constructing a different reality from that of poor people, resulting in a number of undervalued aspects of poverty and deprivation experienced by the poor, including vulnerability, seasonality, powerlessness and humiliation.
} 
purchased material, and a strong influence of social-cultural considerations in decision making processes (Wharton 1969). Conventionally, subsistence farming is viewed as a marginal way of life due to geographical and economic weaknesses (Sacks 1995). In Indonesia, customary laws that govern a subsistence way of life are often linked to connotations like "primitive" and "inferior". For instance, in West Timor, the huge spending for wedding and funerals put additional burden upon households and caused rural Timorese in Indonesia to have no savings (Setiawan 2007).

The practice of subsistence farming has been argued as more than mere survival. Some studies found that a subsistence way of life continues to be retained by some rural households because it represents the source of community resilience (Thornton 2001; Crane 2010; Colombi 2012). In other studies, subsistence-based households are distinguished from the general farmers: the small-scale commercial farmers depend on capital-intensive agriculture to maintain production and are susceptible to price variability, while subsistence-based farmers follow the seasonal cycle in their production and are less affected by price fluctuations (Fisk 1975; Larsen 2009; Kuokkanen 2011; Davidova et al. 2012).

Gudeman (1978), in his concept of necessity, argues that subsistence is an ideology centered on necessity. As described in his work in Los Boquerones, a small village in Panama, men there work hard to maintain the sustenance of their family and avoid being in debt to others as they fear to lose the respect of their peers in the community. Similarly, Seavoy (2000) asserts that peasants are motivated by social goals (contentment via subsistence), not economic goals (to acquire and save money). Seavoy describes that peasants' goal is to have only enough money for their socially acceptable needs and pleasure such as jewellery, livestock, bicycle, or additional wives. Therefore, they are not motivated to earning incomes through credit saving and market sales (Seavoy 2000). Thus, the notion of subsistence in rural society may not simply infer the scarcity aspect in the developmental stage; rather, it indicates how rural people find contentment in meeting what is called 'socially acceptable necessity'. In other words, being content may not necessarily be the result of increased productivity, production or incomes, even though this may improve their purchasing power.

As a result of global warming, climate-related problems are projected to increase in the future and rural poor are expected to be the most vulnerable groups (Special Report of IPCC Working Group II-Watson et al. 1997; Asian Development Bank [ADB] 2012; Hossain and Selvanathan 2011). In the fourth report of the IPCC discussion on the impact, adaptation and vulnerability of rural areas, the subsistence farming community is classified as the same as the general rural poor and is grouped into smallholder agriculture (Parry et al. 2007). Hanh et al. (2009) and Schwarz et al. (2011), adopting the IPCC's definition, chose subsistence households as a target population to measure the vulnerability of rural people to climate change. Schwarz et al. (2011) identified three variables of local governance which influence people's perception of their community's ability to cope with crisis in the future: 'household's participation in communal activities'; 'household's support and respect for community leader's decisions'; and 'household's perceived strength of leadership'. Similarly, Hahn et al. (2009) also found that community bonds and a high level of trust among resource-dependent communities can contribute to reducing vulnerability to extreme weather changes.

Other studies which focus on the socio-cultural aspects of dryland subsistence groups included the vulnerability of farmers' and pastoralists' livelihoods in the African region (Crane 2010; Sallu et al. 2010; Fraser et al. 2011), and herders in Inner Mongolia (Li and Huntsinger 2011), where all of these studies found that over the period of rural development, these communities experienced diminishing rights to claim and access resources. 


\section{Conceptual Model}

The conceptual model of this study is depicted in Figure 1. It illuminates visually the main concepts and the linkages among them to generate information in order to allow effective evaluation to address issues for an under-represented group.

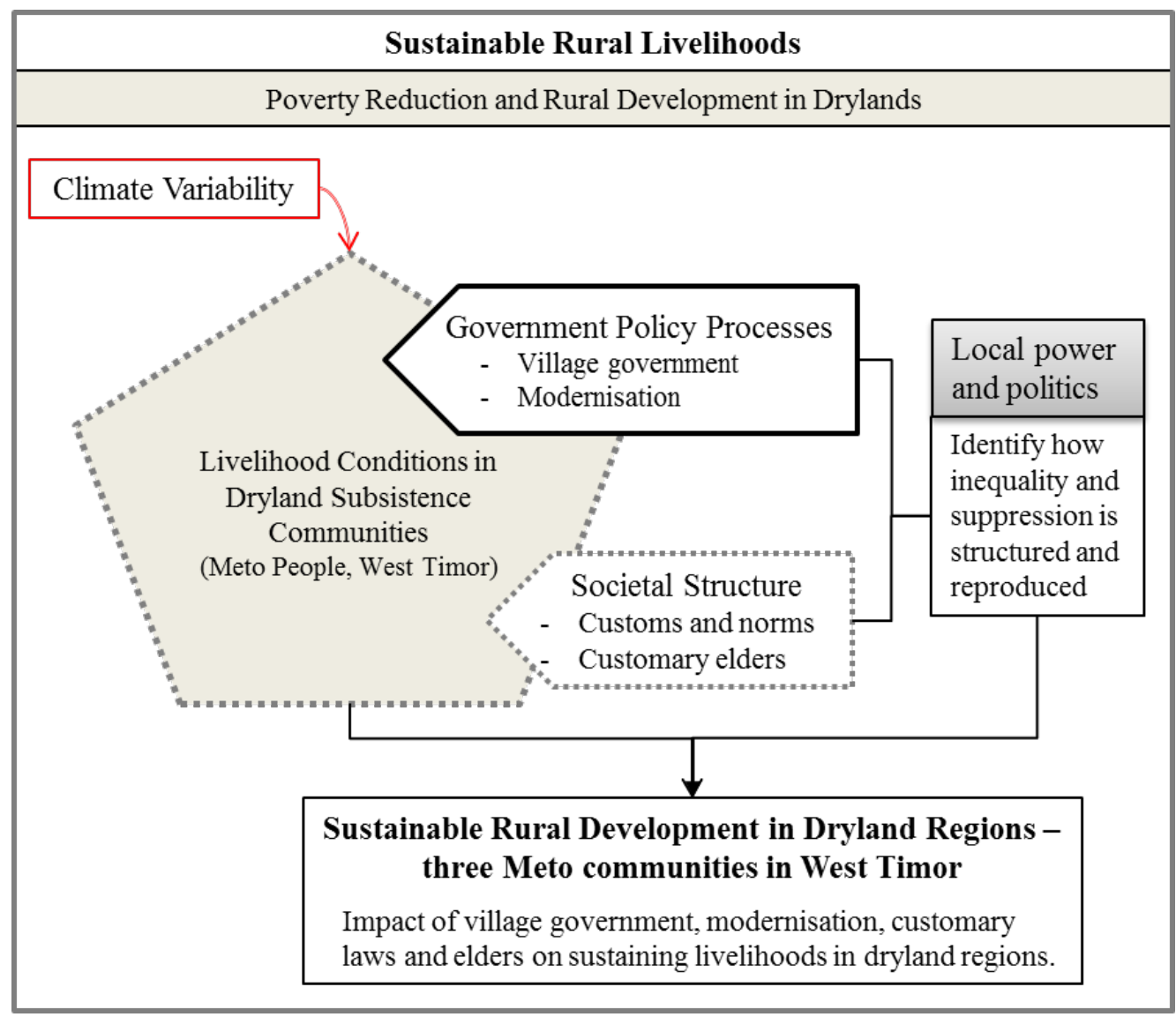

Figure 1: Conceptual model

\section{Study Area and Research Methodology}

\section{The Study Area}

This study is conducted in three Meto communities in rural West Timor: one community (B) is located in Kupang regency and the other two communities (A and C) in Timor Tengah Selatan (TTS) regency (shown in Figures 2 and 3). From years 2008 to 2011, according to Regional Meteorology Bureau in Kupang, the average annual rainfall recorded in its capital city, Kupang was $1,785 \mathrm{~mm}$ (256 days/year without rain). On the other hand, for the same period, TTS Regency's Agricultural and Food Security Agency recorded an average of 2,134mm annual rainfall (237 days/year without rain) in its capital city, Soe. In both regencies, the highest intensity of rainfall occurs between early December and mid-March, with the rest of the year being dry and hot. The highly fluctuating weather has a decisive impact on local food production. 
During the data collection period, there were mixed responses among the Meto communities to the natural resource exploration projects. Some said that they saw these projects as opportunities to develop their region, while others expressed that they were against large-scale projects on their land as it had led to more landslides which blocked their access to farm lands for corn growing.

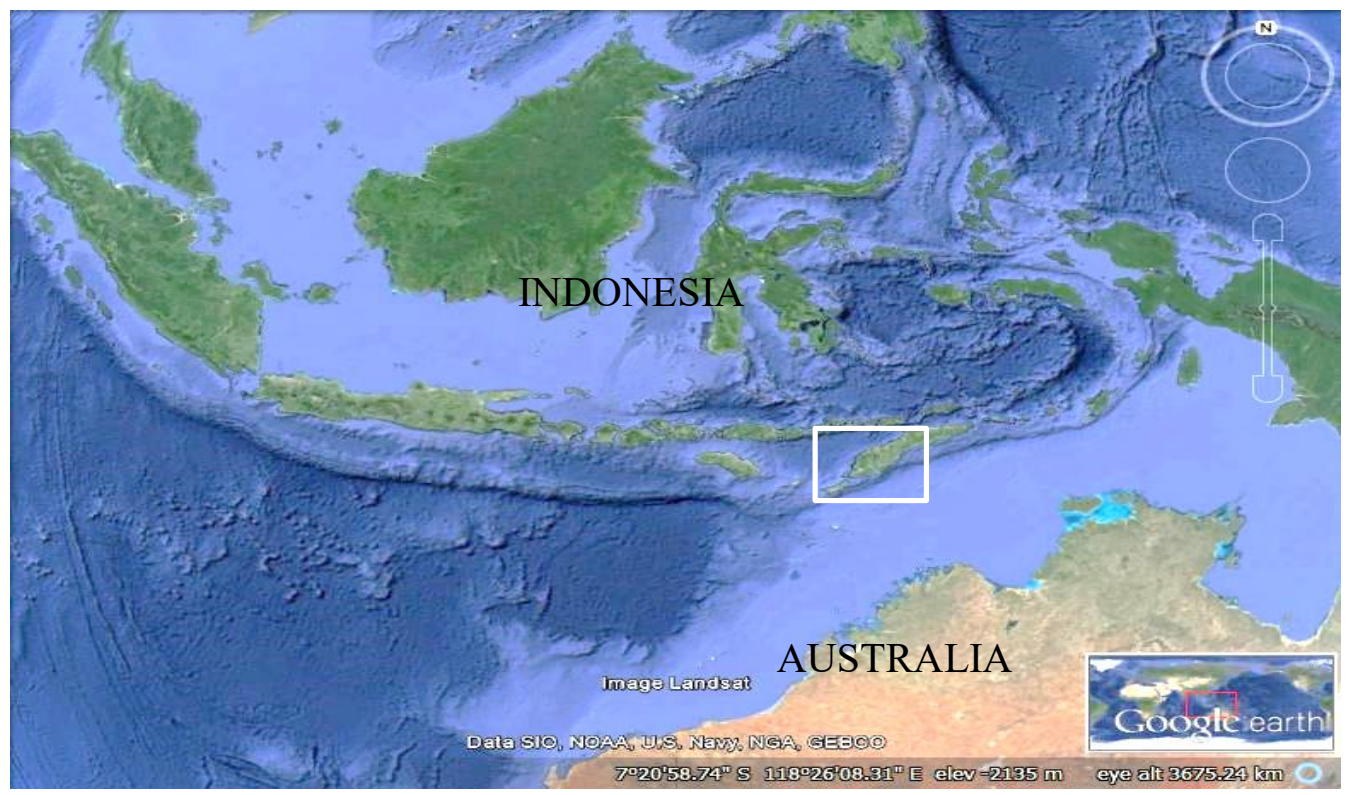

Figure 2: Map of Indonesia, Part of Australia, and the Study Area West Timor (White Box)

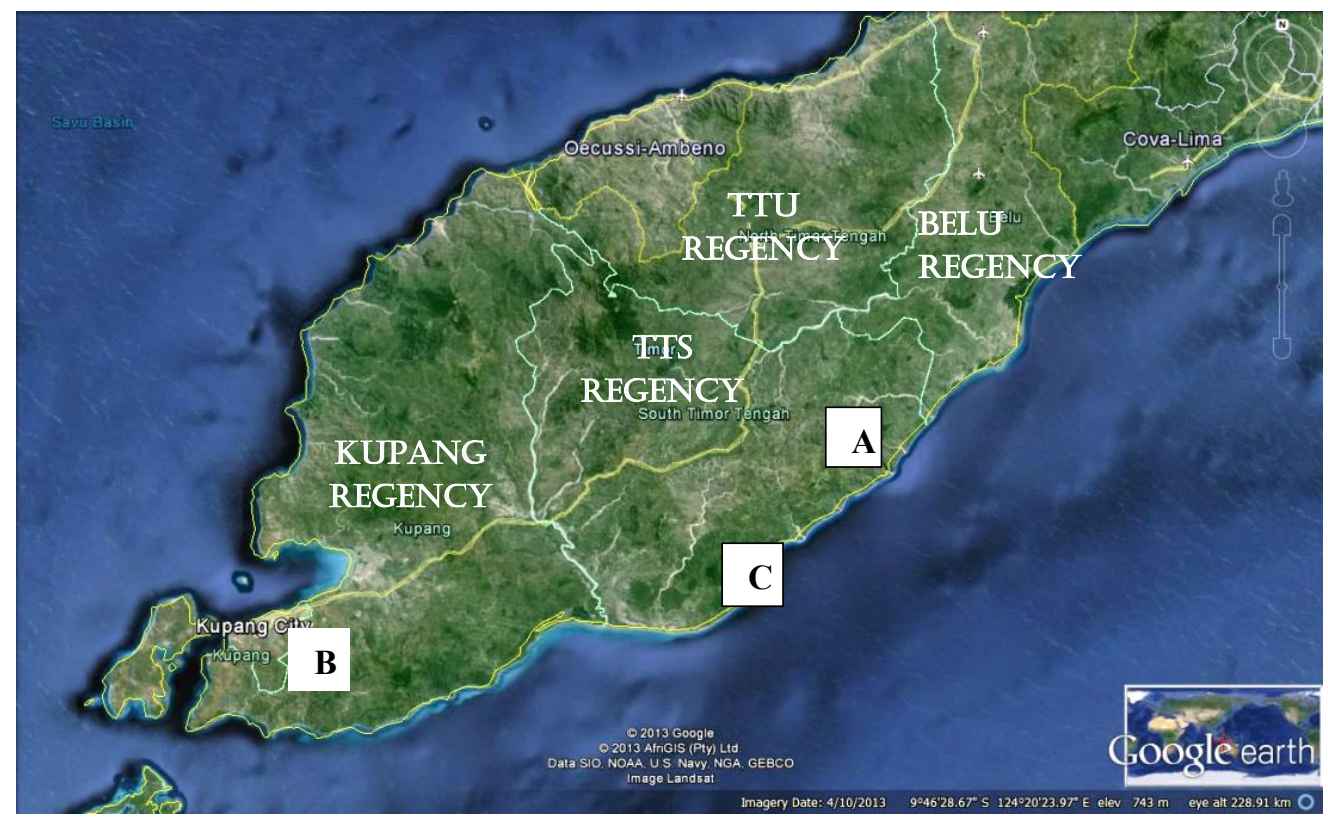

Figure 3: Study Area (West Timor) Comprised of Three Meto Communities:

Community B in Kupang Regency and Communities A and C in TTS Regency 
Table 1: Administrative Unit in West Timor Island, Indonesia (Research site)

\begin{tabular}{|c|c|c|}
\hline Unit & Name & Size \\
\hline Province & East Nusa Tenggara (NTT) & $75,076 \mathrm{~km}^{2}$ \\
\hline Island & West Timor & $15,850 \mathrm{~km}^{2}(1.9$ million people in 2012$)$ \\
\hline Tribe & Atoin Meto (Meto) & Approx. $2 / 3$ of West Timor population \\
\hline Regency & $\begin{array}{l}\text { Kupang } \\
\text { TTS }\end{array}$ & $\begin{array}{l}5,898 \mathrm{~km}^{2} \\
3,947 \mathrm{~km}^{2}\end{array}$ \\
\hline $\begin{array}{l}\text { Area/Altitude/ } \\
\text { Total } \\
\text { households }\end{array}$ & $\begin{array}{l}\text { Community A } \\
\text { Community B } \\
\text { Community C } \\
\end{array}$ & $\begin{array}{l}11.8 \mathrm{~km}^{2} / 664 \mathrm{~m}-1100 \mathrm{~m} / 505 \text { Households } \\
12.6 \mathrm{~km}^{2} / 300-400 \mathrm{~m} / 453 \text { Households } \\
22 \mathrm{~km}^{2} / 7 \mathrm{~m}-250 \mathrm{~m} / 437 \text { Households }\end{array}$ \\
\hline Hamlet & Sub-Village (Dusun) & $\begin{array}{l}\text { Community A: } 3 \text { Dusuns } \\
\text { Community B: } 7 \text { Dusuns } \\
\text { Community C: } 4 \text { Dusuns } \\
\text { Total households per dusun: } 32 \text { to } 184\end{array}$ \\
\hline Forest range & Community forest & Between 10ha and 38ha \\
\hline Water Source & $O e$ or $u i$ & $300 \mathrm{~m}-500 \mathrm{~m}$ from residential areas \\
\hline Household & Farmer family & housing: $30 \mathrm{~m} \times 40 \mathrm{~m}$ (3 -5 members $)$ \\
\hline
\end{tabular}

\section{Methodology}

Data collection was conducted in West Timor between June and November, 2013, as part of a doctoral research into rural livelihoods, drought adaptation, and decentralization impacts by a research team from Griffith University. The research sites were identified based on the gaps in literature, consultation with local academics and practitioners in rural development areas, including IRGSC (Institute of Resource, Governance and Social Change) and FAN (Forum Academia NTT). This study employed a case study approach and collected qualitative primary data through semi-structured group interviews, non-structured in-depth interviews, and participant observations.

The research was initiated through community churches assisted by local guidance including district officers and villagers in the three sites. Involvement of participants was first based on personal willingness to discuss the topics, leading to recommendations by participants (snowballing), and the establishment of working relationships with the researcher. Group interviews were organized according to the participants' genders and social status in the community. For example, housewives were interviewed separately from the male farmers' group, while socially respected members (e.g. teacher, the heads of women's organization and the head of church committee) were interviewed together in the same group. In-depth individual interviews were conducted with the community's influential people such as customary elders, school principal and pastor who have contributed to community building.

Interviews were conducted informally and guided by prepared questions. The questions were designed to obtain information on achievements, losses and changes that occurred in the community and things that they perceive as the biggest challenge to the community in the future. Throughout all interviews, the researcher was accompanied by a local translator to ensure correct interpretation of the terms and meanings. Interviews were conducted in Bahasa Indonesia, with a few combinations of Meto language. A digital recorder was used to record all interviews.

Data was analyzed using grounded theory coding based on the guidance in Strauss and Corbin (1998), Glaser (1978), and Flick (2009). To resolve the issue of analyzing data in a language other than English, this research followed the "translation-during-analysis" approach suggested by Suh et al. (2009) to ensure that the implicit meanings expressed by participants remain intact. 


\section{Findings}

\section{Results}

The results show that customary norms are an important feature of a subsistence community; it governs an individual's conduct, manages resources and requires members to obey the leader. This societal structure causes the communities to be reticent to challenge the elders and the authorities. As a result, the village head takes advantage of this societal structure and abuses his power as a village authority. The following two themes present the results. Each theme consists of three sections: a preamble, evidence of representative quotes from the interviewees, and finally a summary paragraph.

\section{Theme 1: Clan system, customary norms and increasing utility of cash money}

The clan system and customary norms are important components of the Meto communities. They govern an individual's conduct, manages resources and requires members to obey the leader. The people are grouped into different ladders, known as Ume (house of the descendants of a common ancestor). As shown in Figure 4, the clan system in community B consists of four Ume, namely:

(1) Tamukung ('chief', or leader/founder of a community);

(2) Panglima ('commander');

(3) Pekerja ('labourers', originally families who did not own land and who live in the community by share-cropping); and

(4) Kekerabatan ('relatives' or kin who originally came from other villages to live temporarily).

These four Ume are tied into one Main Ume (Clan) as a social unity. The elders in the Ume Tamukung and Ume Panglima are regarded as the Atoin Amaf (the father of hamlet). The clan name generally bears the name of the original chief from Ume Tamukung. In communities A and $\mathrm{C}$, a similar concept to the Ume system was described by their customary elders. The terms Tamukung and Panglima are also mentioned in Cunningham (1967), Schulte Nordholt (1971), and McWilliam (1999) as important leaders of Timorese Domain during the Dutch colonial period.

A clan has its community farmland range as well as community forest. Clan members inherit a certain block of farmland and are granted access to 'forest' as their rights for livelihood. Almost all of the individual households perform bikin kebun (corn growing) in their own farmland as a strategy for food security. This practice requires a male head of household to be consistently working on the same activities in clearing land for at least two months a year, while his wife also actively looks for ways to improve their living conditions. For the people, bikin kebun is regarded as a sign of industriousness and self-sufficiency. The commonly used phrase is: today's harvest equals one year of the household's maintenance.

Identity as clan members remains regardless of the actual residence of the members. When members decide to migrate to another village for marriage or economic reasons, they give up their subsistence rights in the homeland but they, or their children can return to live in the homeland after consulting with Atoin Amaf. The right to subsistence in the homeland is then regained by offering labour to work on a piece of land owned by their kin or shared by the Ume they are associated with. This type of share-cropping subsistence, known as 'garap', is still commonly practiced in West Timor.

In addition to corn, the Meto people cultivate a variety of produce in their community forest, including foodstuffs such as cassava, pumpkin, papaya, banana, lima beans (Phaseolus lunatus), and rice beans (Vigna umbellate), mango, apple guava, tamarind (Tamarindus indica), and kemiri (candlenut), and building materials such as palm trees, lamtoro (Leucaena leucocephala), mahoni (broad-leaf mahogany), jati (teak or tropical hardwood), and gamal (Gliricidia). Community forests provide the Meto communities with alternative food and resources that 
support them in post-crisis periods, for instance, when they need materials for roof replacement after a massive windstorm, or when they need cash to buy food in the market to cope with crop failure.

According to most of the interviewees, social cohesion in their community is still strong. People gathered and organized themselves for social activities or to improve common resources (e.g. water, road and church).

"If the work requires 10 to 20 people to help, we will buy drinks and prepare food, we will finish the work and then have a rest there, enjoy the drinks and food until we fall asleep. The work will be finished before we start having fun. In here, the social [solidarity] is still high"

(OJ, figure head of the community)

However, many of them also admitted that they are struggling to allocate their time and energy into cash-income activities and the subsistence food growing tradition. This is because the need for cash money for these subsistence households has increased, especially for the education expenses of their children.

"In the [women's] group we discuss together, but after we go home, it is individual's business. It works. Otherwise our children would not have gone to school and obtained education.

"We must manage our time well"

(Housewives' Group)

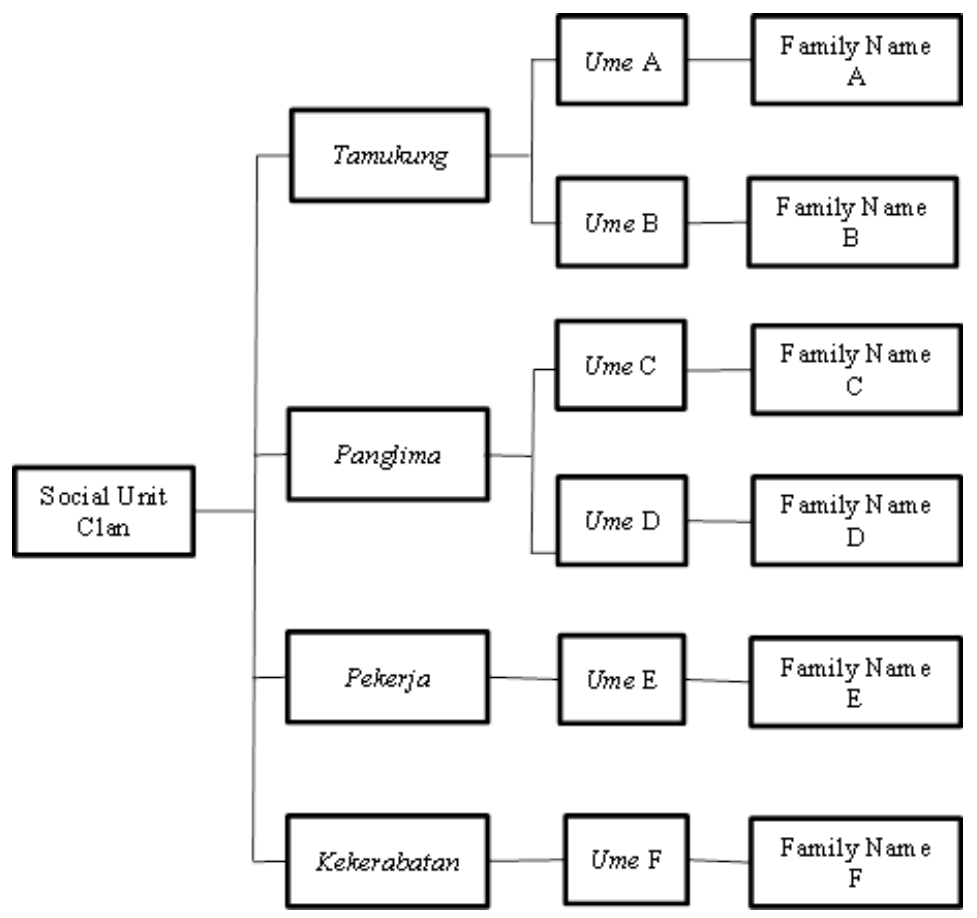

Figure 4: Example of Social System of a Meto Clan in Community B

A female member in the community used to grow her own food but now she tries to find other work to generate cash income. She said: 
"The parents and elderly want to return to subsistence farming and make kebun [garden], but the current daily needs [for money] made it difficult to allocate time and energy. If only there is enough energy, we want to do both [subsistence farming and cash generating work], it all depends on how we can meet the daily needs"

(YL, orang tua)

\section{Summary}

Subsistence corn farming as a livelihood of the Meto people is being compromised to meet their daily needs. The Meto people gradually choose to look for cash-generating work to ensure their children can obtain education. However, the Meto clan system and customary laws continue to act as informal authority in governing members' conduct, define their status and grant rights to access resources.

\section{Theme 2: The Village Head}

Based on the expressions provided by respondents in the three regions, at this moment they are not satisfied with the performance of their village heads. Some approaches have been taken by these communities but their strong respect for customary laws made them reticent and reluctant to directly question the accountability of the village head due to his status as orang tua. In all the three communities, orang tua refers to a social title that is given to high-ranking members (both female and male) in the community who are generally the descendants of former kings. The orang tuas own more animals and lands than the folks in the community.

In communities $\mathrm{B}$ and $\mathrm{C}$, the village heads, their wives and children do not live in the village, and they have their business in the urban region. According to the local people, they voted for someone who had some business skill and connections with the market in the hope that their produce could be marketed easily to improve their livelihood and the economy of the village as a whole. Being dissatisfied with the head of the village, the people held regular meetings with an expectation that the influential figures in the community would make time to participate; in this case the customary elders, the representatives of church and school, and the aparat desa (village officials), including the members of BPD (village parliament) and the village head. However, the head of village rarely attended the meetings, hence the customary elders and village representatives, together with the villagers internally made a decision to not reelect the head of village in the next election. In contrast, community A has had the same head of village for over 20 years. The people all expressed their complaints during interviews, but it seems as though they did not have the same ability to stand against the village head as the other two communities (B and C) during village election.

During the data collection period, there were many occasions that the researcher attempted to meet the five heads of village in the three studied communities. However, most of them were hardly seen in the village. In the village office, there were only some students (doing $K K N$, practicum internship) and a few village officials. Out of the five villages, only two village heads (one in B and the other in C) showed up for interview. The other two village heads (B and C) were outside the village for official meetings. And another one (in A), according to the local escort, was too scared to be interviewed as he had heard that the researcher had conducted an interview with a local customary elder in his village. Apparently, according to the local people, this customary elder has bravely challenged the village head; consequently this village head took revenge by blocking the people within the dusun (hamlet) of this customary elder from receiving raskin (rice subsidy for the poor) and many other aids.

The following selective quotes from interviews provide the evidence. 
"Our village looks the same, from Orde Baru until now [20 years]. Even in decentralization era, there is grant allocated to village [from central], still no work program... nothing in here."

"He [head of village] only thinks about how much he gets by attending those [official] meetings, because there's lack of jobs available... The point is... for him this position is a job that gives income and how much he earns [from it]. And he only employs family and relatives. Look at the National and Regional Funds...gone... all is in their stomach."

(SL, figure head in the community)

"If the village government doesn't act, certainly the village is going to die. Here we have plenty of produce, too much for one family. They just don't know where to sell [the excess]. The market here is only once a week."

"Here we need a head or leader who can lead and engage with the people and the customary elders to sit down and give direction."

(ET, customary elder)

"The leader in village has a very important role, but at this moment a good head of village is not yet found."

(YB, worked outside village)

For the Meto people, the village head is an immediate role model in reinforcing rules and regulating people's behaviour. When the village head did not fulfil their expectations, they would refuse to comply with his command.

"[We are aware that] we are low educated and less knowledgeable [than the village head] because we have less contact to the outside world. But we can and are willing to gotong royong [mutual cooperation] to work together as long as the important figures are invited and give explanation to the people. Everyone [the people] will listen to these leaders [important figure].”

(Mixed Group)

"What we proposed to him [head of village], he regarded as threats, [he is afraid] that we want to become head of village... we want to take his land... He [head of village] never supports our proposal, he has no vision to move forward [towards development], and he led in the way to protect position"

(ET, customary elder)

For some villages, the people and customary elders could only resign themselves to the situation, while others made their own decision to overcome the state of deprivation, using available resources.

"The water cistern built from government aid is not functioning at all because the village head does not act to correct the issue with the land owner [the people in charge of managing the water cistern are family relations to the head of village and have a higher rank in the family], people just let it be."

(OJ, figure head in community)

"The people are still reluctant [to question or challenge] the elderly, they just remain reticent, let alone the head of village. Hence, the head of village can do anything without [having to be worried about] protests and complaints [against him] from the people." 
"Previous village head managed his cattle well and didn't let them out freely, the people followed his example, and everyone felt safe and comfortable during his period. The current village head has many cattle but they are let go freely anywhere in the neighbourhood, destroying our garden, we simply can't grow anything here"

(YL, orang tua)

'Yes, there is village representative body and also formal rules, but the members' education is still minimal, only elementary level. The rules are made but never disseminated to the people. So our basis to speak up is limited. It also is difficult for them [members of village representative] to speak up, in front of the authority, their voice is weak"

(AB, school teacher)

"....the [government] aid came down from top but didn't reach here [our community], so the people here become self-supporting, we take care of our own business [healthy house and toilet, electricity...]"

(ET, customary elder)

\section{Summary}

The village head, as the official authority in the village system, failed to build a good relationship with the customary elder and the people in the community. Consequently, the people distanced themselves from the village government; some even became marginalized by the village head after they attempted to speak in protest. The social position of rural communities in West Timor remains weak in relation to their village head, for the village head possesses status in both social and administrative levels.

\section{Analysis}

In all three communities, people are very reluctant to directly admonish the village head and village officials. Even the customary elders, who are regarded as highly ranked members in the clan system, do not make direct complaints to the village head. To remind the village head of his responsibilities, they hold meetings to give him an opportunity to improve. Unfortunately, this procedure merely allows the village head to continue to procrastinate.

This study finds that there are three factors leading to the under-performance of village heads such as the one described in community A. Firstly, the village head has no other income source. In the case of communities B and C, the village heads were doing business before they took up the position. When the village head has no other income source, there is a financial threat to him if he is not re-elected. If he seriously abuses his power causing a huge loss to the community, his flaws are likely to be disclosed by the upper-level of government. By appropriating small amounts on a regular basis, this village head can surreptitiously accumulate additional income from the grants that are allocated to build the village.

The second factor is that there is no competitor or alternative potential leader for the people to choose. In community B, an alternative potential leader existed, but the people hesitated to consider him due to his alcoholic problem. In contrast, in community A, they have a number of highly educated people who have settled well outside the village, including a nurse, head of police, lecturer, and even a member of DPRD (Regional People's Representative Assembly) for NTT Province. However, these people rarely return to the village, thus there is no eligible candidate to stand against the village head. Finally the third factor is the customary norms that require members to respect the leader and authority figures. In the Meto belief system, Uis Pah (the King of Earth) refers to their influential ancestors (territorial kings) who protected and 
governed their land during the Atoin Meto Domain system (Cunningham 1967; Schulte Nordholt 1971; McWilliam 1999, 2002). The Meto people continue to pay respect to their ancestors (including the descendants) as the protectors of their land. As a result, the people are reticent and reluctant to admonish the village head, especially as the village head is the descendant of their former king.

The worst scenario is when the first and the third factors are applied and the personnel in BPD and village administration are recruited based on their kinship with the village head, rather than their capability to monitor and guide the village head. As in the case in community A, the village head has the supremacy to maintain his status quo because the monitoring body, BPD, is not functioning independently and the traditional leader has no formal authority and lacks educational competency to take legal action. To legitimate his status quo, the village head feels the need to demonstrate his power over the community by exercising control. The blocking of raskin and other aids demonstrates his vulnerability in facing the challenge exerted by the customary elder.

\section{Discussions}

In dryland areas like West Timor, the topography and land characteristics are very diverse, even within the village. Cultural practice in the form of rituals and gatherings are found to be economically and spiritually beneficial for the Meto People (Schulte Nordholt 1971) as well as the other traditional communities in the Eastern part of Indonesia (McWilliam 2009). The activities involved in the ritual gatherings help link members together, maintain emotional ties and facilitate the transmission of collective knowledge, thus allowing the Meto people to trace their origins through the journey of their ancestors (McWilliam 1999, Fox 1999). The influence of clan as a political and social unit was recognized as the sub-unit of Swapraja where local 'tamukung' was elected as the keeper of the communal system to ensure order in the village during the Dutch occupation (Schulte Nordholt 1971; McWilliam 1999). However, in postIndependence Indonesia, the clan's authority began to fade, particularly since the 1960s when the established Swapraja administration was eliminated nationwide in 1965 and replaced by centrally appointed personnel to administer the affairs at regional levels, from province to village.

This study finds that the clan customs which originally functioned to provide social order and regulate members' conduct in accessing resources have shaped the submissive culture in rural West Timor, causing the repressive societal structure to reproduce itself throughout the ever changing bureaucratic systems. Diminishing authority and lack of educational competency in the traditional elders have resulted in a community unable to fight against the social pressure exerted by a corrupt village government. Subsistence communities in West Timor are frustrated by their village heads who do not have work programs and misallocate grants that were allocated to build the village. In addition to climate change, these cumulative social problems make subsistence communities in dryland areas more vulnerable.

In regards to development policy, in West Timor and other Eastern parts of Indonesia, the role of local communities in sustaining rural ecosystems has received little attention from the government. During the developmental era in the 1980s, many of the previously isolated forest areas in these regions were transformed into roads or opened up to meet the increasing demands for watershed protection, biodiversity conservation, recreation, and commercial projects (Fisher et al. 1999). Communities in and around these resource areas are rarely involved in the decision making process (Fisher et al. 1999) although their rights over land and water are recognized de facto and de jure ${ }^{5}$.

\footnotetext{
${ }^{5}$ In the State of the Republic of Indonesia, the rights over land and water of resource-dependent community are stated in Law No.5/1960 (Basic Regulations on Agrarian Principles), Law No.41/1999 (Forestry), Law No. 22/2001(Petroleum
} 
Also, in the nation's development policy, the status of communities who practice a traditional way of life, like the Meto people, seems to be left out. The nation calls these communities Komunitas Adat Terpencil (Geographically Isolated Customary Law Communities) (Wirajuda 1999). This title for traditional communities tends to indicate the poverty and primitive aspect of this group (Duncan 2004). It also tends to suggest that these communities are poor and need to be integrated into the wider modern society (Wirajuda 1999; Duncan 2004; Bamba 2008; Country Technical Note on Indigenous People's Issues: Republic of Indonesia [Aliansi Masyarakat Adat Nusantara (Indigenous People Alliance of the Archipelago)-AMAN] 2012). The government does not apply the international legal category to define 'indigenous people', because the word 'indigenous' is literally translated as pribumi in Indonesian language, which is used to differentiate the local people from the small Chinese community (Duncan 2007). This lack of understanding of a community's value has often led the outsiders to regard rural people's customary laws as an additional burden to members (overspending for wedding and funerals) and causing the rural people to have no savings (Setiawan 2007). During the fieldwork of this study, some outsiders also took advantage of local clan social bonds to facilitate the spread of information for political interest (election votes) or economic interest (resources exploitation).

From the debates in the development literature, policy for rural poverty eradication in postWWII has been criticized as failing to develop the human resources of the poor (Streeten and Burki 1978; Streeten 1984), ignoring the issue of inequality (Griffin and Khan 1978), ignoring livelihood capabilities (Chambers 1995), and overlooking the impacts of power and politics in rural society (Scoones 2009). This case study provides evidence that indeed the development policy has overlooked the welfare of the traditional subsistence-based communities, and that their traditional values and customs are being abused by the bureaucratic system. With limited finance and technological resources, educated people prefer to leave the village for income in the urban areas. The consequence of this shortage of human resources is that it impedes rural development and increases the hardship of the under-educated people who stay in this community, intensifying livelihood vulnerability of the dryland communities in West Timor.

Further, this study confirms with the conclusions of Schwarz et al. (2011) and Hahn et al. (2009), that local governance plays a key role in community resilience. However, in terms of the pressures from development and monetization on dryland subsistence communities, this study has a different argument from the existing studies. Livelihood vulnerability of the dryland subsistence communities in the African region (Crane 2010; Sallu et al. 2010; Fraser et al. 2011) and Inner Mongolia ( $\mathrm{Li}$ and Huntsinger 2011) are found to be due to their diminishing rights to claim and access resources during their rural development period. Our case study in West Timor shows that while the clan system continues to provide the communities the right to claim natural resources, on the other hand, their issue is with the village heads who take advantage of the societal structure and abuse their authority. Our finding adds further argument that resourcedependent communities tend to be bound by customary laws in management of natural resource and human relations, and their respect for leaders implies that adaptive capacity to economic and climatic shocks are greatly related to the leadership of the customary elders and village head.

The limitation of this study was the composition of the study participants. First, the sample was limited to participation at village level; and second, involvement of participants was based on personal willingness and "snowball" technique rather than randomly selected. These might have biased the sample. Obtaining insights from the upper-level of government (i.e. the heads of district and regency) to cross-check the responses of participants would have been desirable. Further research should also examine the influence of inter-marriages and house of descendants 
on local governance, particularly accountability of a district head and a regent to village and clan members.

\section{Conclusion}

This paper has demonstrated that the clan system and customary laws play an important part in the livelihood of subsistence communities in West Timor. The clan system and customary laws define the power relationship between clan members, maintain connection and mutual support among members, and provide members with access to land and natural resources. The introduction of formal administration into rural societies over the period of changing government systems has not appropriately considered the role of clan and customary laws in the adaptive capacity of resource-dependent communities, particularly in dryland regions.

For a sustainable development in dryland regions, rural capacity building should look into ways to overcome the flaws in village government, in order to give the rural people a sense of security, hopefulness and trust about the future outlook of their village. Also, customary laws contribute to a sustainable livelihood and preservation of local knowledge and natural resources and should be included in the government decision-making and local policy.

\section{Acknowledgement}

I would like to acknowledge Associate Professor Moazzem Hossain and Dr. Peter Davey for their comments and assistance on an earlier draft of this paper. I also would like to thank both reviewers for their insightful comments on the paper as these comments led to the improvement of the work. Lastly, I am deeply grateful to the Meto people and the local helpers and communities in the three study regions of this research for their participation and hospitality during my data collection period in West Timor. I respectfully acknowledge the contribution of the Meto people in the maintenance of natural resources in West Timor.

\section{REFERENCES}

Asian Development Bank (ADB). 2012. Addressing Climate Change and Migration in Asia and the Pacific. Manila, Philippines: Asian Development Bank.

Aliansi Masyarakat Adat Nusantara (Indigenous People Alliance of the Archipelago-AMAN). 2012. Country Technical Note on Indigenous People's Issues: Republic of Indonesia. IFAD (International Fund for Agricultural Development) and AIPP (Asia Indigenous Peoples Pact). https://www.ifad.org/documents/10180/a1 fe61f8-837b-4d94-b1b7-da17c3543d14.

Bamba, John. 2008. "Recognition 'In Kind': Indonesian Indigenous Peoples and State Legislation." In The Concept of Indigenous Peoples in Asia, edited by Christian Erni, 257-274. Copenhag en: International Work Group for Indigenous Affairs (IWGIA) and Asia Indigenous Peoples Pact Foundation (AIPP).

Banerjee, Abhijit V. 2000. “The Two Poverties.” MIT Department of Economics Working Paper 01-16. doi.org/10.2139/ssrn.271731.

Barbier, Edward B. 2000. "The economic linkages between rural poverty and land degradation: some evidence from Africa." Agriculture, Ecosystems and Environment 82: 355-370. doi:10.1016/S0167-8809(00)00237-1.

Barlow, Colin, and Ria Gondowarsito. 2007. Socio-economic Conditions and Poverty Alleviation in NTT. Canberra, Australia: Australian National University.

Badan Nasional Penanggulangan Bencana (National Bureau for Disaster Management of the Republic of Indonesia-BNPB). 2009. Peta Kejadian Bencana di Propinsi Nusa 
Tenggara Timur Tahun 2008 (East Nusa Tenggara Year 2008 Natural Disaster Incidence Map). Jakarta: Badan Nasional Penanggulangan Bencana.

Badan Pusat Statistik NTT (Bureau Statistics-BPS NTT). 2014. NTT Dalam Angka 2013 (NTT in

Figures Year 2013). Kupang City: Badan Pusat Statistik NTT.

Badan Pusat Statistik NTT (Bureau Statistics-BPS NTT). 2015. Produk Domestik Regional

Bruto Menurut Lapangan Usaha, 2004-2013 (Gross Regional Domestic Product by Industrial Origin, 2004-2013). Badan Pusat Statistik. Accessed December 20, 2015. http://ntt.bps.go.id/linkTableDinamis/view/id/41.

Chambers, Robert, Arnold Pacey, and Lori Ann Thrupp, 1989. Farmer First. London: Intermediate Technology Publications.

Chambers, Robert. 1995. "Poverty and Livelihoods: Whose Reality Counts?" Environment and Urbanization 7(1): 173-204. doi:10.1177/095624789500700106.

Cleaver, Kevin M., and Götz A. Schreiber. 1994. Reversing the Spiral: The population, Agriculture, and Environment Nexus in Sub-Saharan Africa. Washington, D.C.: World Bank.

Collinson, Michael P. 2000. A History of Farming Systems Research. Rome, Italy: Food and Agricultural Organization of the United Nations.

Colombi, Benedict J. 2012. "Salmon and the Adaptive Capacity of Nimiipuu (Nez Perce) Culture to Cope With Change." American Indian Quarterly 36 (1): 75-97. doi:10.5250/amerindiquar.36.1.0075.

Crane, Todd A. 2010. "Of Models and Meanings: Cultural Resilience in Social-Ecological Systems.” Ecology and Society 15 (4): 19pp.

http://www.ecologyandsociety.org/vol15/iss4/art19/.

Cunningham, Clarke. E. 1962. "People of the Dry Land. A Study of the Social Organization of an Indonesian People." Ph.D Thesis, Oxford University.

Davidova, Shopia, Lena Fredriksson, Matthew Gorton, Plamen Mishev, and Dan Petrovici. 2012. "Subsistence Farming, Incomes and Agricultural Livelihoods in the New Member States of the European Union." Environment and Planning C: Government and Policy 30: 209-227. doi:10.1068/c1195r.

de Janvry, Alain, Marcel Fafchamps, and Elisabeth Sadoulet. 1991. "Peasant Household Behaviour with Missing Markets: Some Paradoxes Explained.” The Economic Journal 101(409): 1400-1417. doi:10.2307/2234892.

Duflo, Esther. 2006. "Poor but Rational?" In Understanding Poverty, edited by Abhijit Vinayak Barnerjee, Roland Bénabou and Dilip Mookherjee, 367-378. Oxford: Oxford University Press.

Duncan, Christopher R. 2004. "From development to empowerment: Changing Indonesian Government Policies towards Indigenous minorities." In Civilizing the Margins: Southeast Asian Government Policies for the Development of Minorities, edited by Christopher R. Duncan, 86-111. Ithaca, New York: Cornell University Press. 2007. "Mixed Outcomes: The Impact of Regional Autonomy and Decentralization on Indigenous Ethnic Minorities in Indonesia." Development and Change 38(4): 711-733. doi:10.1111/j.1467-7660.2007.00430.x.

Eki, Ayub T. 2010. "Kebijakan Pemkab Kupang di Bidang Pertambangan (Kupang District Government Policy in Mining)." Presentation at the Seminar Sehari: Potret Masa Depan Industri Pertambangan Mangan di NTT (One Day Seminar: Portrait of the Future of Manganese Mining Industry in NTT), Universitas Nusa Cendana, Kupang City, Indonesia, November 20, 2010.

Food and Agriculture Organization (FAO). 2004. Carbon Sequestration in Dryland Soils. Rome: Food and Agriculture Organization of the United Nations. 
2008. Climate Change, Water and Food Security. Technical Background Document from the Expert Consultation Held on 26 to 28 February 2008. Rome: Food and Agriculture Organization of United Nations. http://www.fao.org/docrep/016/ap526e/ap526e.pdf.

Fisher, Larry, Ilya Moeliono, and Stefan Wodicka. 1999. "The Nusa Tenggara Uplands, Indonesia: Multiple-Site Lessons in Conflict Management." In Cultivating Peace: Conflict and Collaboration in Natural Resources, edited by Daniel Buckles, 61-79. Ottawa: International Development Research.

Fisk, Ernest K. 1975. "The Neglect of Traditional Food Production in Pacific Countries." Australian Outlook 29(2): 149-160. doi:10.1080/10357717508444531.

Flick, Uwe. 2009. An Introduction to Qualitative Research (4 ${ }^{\text {th }}$ Edition). London: SAGE.

Fox, James J. 1999. "Precedence in Practice Among the Atoni Pah Meto of Timor." In

Structuralism's Transformations: Order and Revisions in Indonesia and Malaysia.

Edited by Lorraine V. Aragon and Susan D. Russell, 1-36. Tucson: Center for Southeast Asian Studies, Arizona State University.

Fraser, Evan D, Andy J. Dougill, Klaus Hubacek, Claire H. Quinn, Jan Sendzimir, and Mette Termansen. 2011. "Assessing Vulnerability to Climate Change in Dryland Livelihood Systems: Conceptual Challenges and Interdisciplinary Solutions." Ecology and Society 16(3): 12pp. http://dx.doi.org/10.5751/ES-03402-160303.

Gisladottir, Gudrun, and Michael Stocking. 2005. "Land Degradation Control and Its Global Environmental Benefits." Land Degradation and Development 16(2): 99-112. doi:10.1002/ldr.687

Glaser, Barney. 1978. Theoretical Sensitivity. Mill Valley, CA: University of California Press.

Griffin, Keith, and Azizur R. Khan. 1978. "Poverty in the Third World: Ugly Facts and Fancy Models." World Development 6(3): 295-304. doi:10.1016/0305-750X(78)90109-2.

Gudeman, Stephen. 1978. The Demise of a Rural Economy: From Subsistence to Capitalism in a Latin American Village. London: Routledge and Kegan Paul.

Hahn, Micah B., Anne M. Riederer, and Stanley O. Foster. 2009. "The Livelihood Vulnerability Index: A Pragmatic Approach to Assessing Risks from Climate Variability and Change: A Case Study in Mozambique." Global Environmental Change 19(1): 74-88. doi:10.1016/j.gloenvcha.2008.11.002.

Hossain, Moazzem, and Eliyathamby A. Selvanathan. 2011. Climate Change and Growth in Asia, Cheltenham, UK: Edward Elgar.

Hunt, Diana. 1991. "Farm System and Household Economy as Frameworks for Prioritising and Appraising Technical Research: A Critical Appraisal of Current Approaches.” In Rural Households in Emerging Societies: Technology and Change in Sub Saharan Africa, Edited by Margaret Haswell and Diana Hunt, 49-76. Oxford, UK: Berg Publisher.

International Labour Organization (ILO). 1976. Employment, Growth and Basic Needs: A OneWorld Problem. Geneva: International Labour Office.

Watson, Robert. T., Marufu C. Zinyowera, Richard H. Moss, and David J. Dokken. 1997. The Regional Impacts of Climate Change: An Assessment of Vulnerability. A Special Report of IPCC Working Group II. Intergovernmental Panel on Climate Change. https://www.ipcc.ch/pdf/special-reports/spm/region-en.pdf.

Johnston, Bruce, and John W. Mellor. 1961. "The Role of Agriculture in Economic Development." American Economic Review 51 (4): 566-593. http://www.jstor.org/stable/1812786.

Kalame, Fobissie B., Olavi Luukkanen, Elnour A. Elsiddig, and Edinam K. Glover. 2010. "Tree Knowledge and Livelihood Activities in a Changing Environment: Views from Smallholder Farmers in Kosti, Sudan." Journal of Sustainable Forestry 29(6-8): 591— 612. doi:10.1080/10549811003742084. 
Kotta, Herry Z. 2010. "Mangan dan Kesehatan, Suatu Tinjauan: Geologi Medis (Manganese and Health, an Overview: Medical Geology)." Presentation at the Seminar Sehari: Potret Masa Depan Industri Pertambangan Mangan di NTT (One Day Seminar: Portrait of the Future of Manganese Mining Industry in NTT), Universitas Nusa Cendana, Kupang City, Indonesia, November 20, 2010.

Kuokkanen, Rauna. 2011. "Indigenous Economies, Theories of Subsistence, and Women: Exploring the Social Economy Model for Indigenous Governance." American Indian Quarterly 35(2): 215-241. doi:10.5250/amerindiquar.35.2.0215.

Larsen, Ana F. 2009. "Semi-Subsistence Producers and Biosecurity in the Slovenian Alps." Sociologia Ruralis 49(4): 330-343. doi:10.1111/j.1467-9523.2009.00481.x.

Lee, James, and Robert Goodland. 1986. "Economic Development and the Environment." Finance and Development 23(4): 36-39.

Li, Wenjun, and Lynn Huntsinger. 2011. "China's Grassland Contract Policy and its Impacts on Herder Ability to Benefit in Inner Mongolia: Tragic Feedbacks." Ecology and Society 16 (2): 14pp. http://www.ecologyandsociety.org/vol16/iss2/art1/.

McWilliam, Andrew R. 1999. "From Lord of the Earth to Village Head: Adapting to the nationstate in West Timor." Bijdragen tot de Taal-, Land- en Volkenkude 155(1): 121-144. http://www.jstor.org/stable/27865494.

- 2002. Paths of Origin, Gates of Life: A Study of Place and Precedence in Southwest Timor. Leiden: KITLV Press.

2009. "The Spiritual Commons: Some Immaterial Aspects of Community Economies in Eastern Indonesia." The Australian Journal of Anthropology 20(2): 163-177. doi:10.1111/j.1757-6547.2009.00024.x.

Mellor, John W. 1966. The Economics of Agricultural Development. Ithaca, New York: Cornell University Press.

Mitchell, Donald O., Merlinda D. Ingco, and Ronald C. Duncan. 1997. The World Food Outlook (Trade and Development). Cambridge, Great Britain: Cambridge University Press.

Morduch, Jonathan. 1994. "Poverty and Vulnerability." The American Economic Review 84(2): 221-225.

https://wagner.nyu.edu/files/faculty/publications/Poverty_and_Vulnerability.pdf.

Mortimore, Michael, and William M. Adams. 1999. Working the Sahel: Environment and Society in Northern Nigeria. London: Routledge.

Muslimatun, Siti, and Silvia Fanggidae. 2009. "A Brief Review on the Persistent of Food Insecurity and Malnutrition Problems in East Nusa Tenggara Province, Indonesia." Institute of Indonesia Tenggara Timur Studies (IITTS) Working Paper 12. http://ntt-academia.org/WP/WP12.Oxfam.Muslimatun.Fanggidae.pdf.

NTT Provincial Government. 2012. State of Environmental Report, East Nusa Tenggara.

Overseas Development Institute (ODI). 1978. Basic Needs, Briefing Paper No. 5. London: Overseas Development Institute.

Parry, Martin, Osvaldo Canziani, Jean Palutikof, Paul van der Linden, and Clair Hanson. 2007. Climate Change 2007: Impacts, Adaptation and Vulnerability. Contribution of Working Group II to the Fourth Assessment Report of the Intergovernmental Panel on Climate Change (IPCC). Cambridge, UK: Cambridge University Press.

Pelling, Mark, and Juha I. Uitto. 2001. "Small Island Developing States: Natural Disaster Vulnerability and Global Ghange." Environmental Hazards 3: 49-62. doi:10.1016/S1464-2867(01)00018-3.

Popovski, Vesselin, and Kieran G. Mundy. 2012. "Defining Climate-Change Victims." Sustainable Science 7(1): 5-16. doi:10.1007/s11625-011-0138-0. 
Sacks, Jeremy D. 1995, "Culture, Cash or Calories: Interpreting Alaska Native Subsistence Rights." Alaska Law Review, 12(2): 247-291.

http://scholarship.law.duke.edu/cgi/viewcontent.cgi?article=1325\&context=alr.

Sallu, Susannah M., Chasca Twyman, and Lindsay Stringer. 2010. "Resilient or Vulnerable Livelihoods? Assessing Livelihood Dynamics and Trajectories in Rural Bostwana." Ecology and Society 15(4): 24pp. http://www.ecologyandsociety.org/vol15/iss4/art3/.

Scherr, Sara J. 2000, "A Downward Spiral? Research Evidence on the Relationship Between Poverty and Natural Resource Degradation." Food Policy 25(4): 479-498. doi:10.1016/S0306-9192(00)00022-1.

Schulte Nordholt, Henk G. 1971. The Political System of the Atoni of Timor. The Hague: Martinus Nijhoff.

Schultz, Theodore W. 1964. Transforming Traditional Agriculture. New Haven, CT: Yale University Press.

Schwarz, Anne-Maree, Christophe Béné, Gregory Bennett, Delvene Boso, Zelda Hilly, Chris Paul, Ronnie Posala, Stephen Sibiti, and Neil Andrew. 2011. "Vulnerability and Resilience of Remote Rural Communities to Shocks and Global Changes: Empirical Analysis from Solomon Islands.” Global Environmental Change 21: 1128-1140. doi:10.1016/j.gloenvcha.2011.04.011.

Scoones, Ian. 2009. "Livelihoods Perspectives and Rural Development." The Journal of Peasant Studies 36(1): 171-196. doi:10.1080/03066150902820503.

Seavoy, Ronald E. 2000. Subsistence and Economic Development. Westport, CT, USA: Greenwood Publishing Group.

Setiawan, Bayu. 2007. Mobilitas Penduduk dan Pengembangan Potensi Perdagangan di Wilayah Perbatasan NTT-Timor Leste (Population Mobility and Potential Development of Trade in Border Region of East Nusa Tenggara Province and East Timor). Laporan Akhir Kumulatif Kegiatan Program Kompetitif LIPI 2005-2007 (Final Report of the Cumulative Activity of the LIPI Competitive Program). Lembaga Ilmu Pengetahuan Indonesia-LIPI (Indonesian Institute of Science).

Strauss, Anselm, and Juliet Corbin. 1998. Basics of Qualitative Research: Techniques and Procedures for Developing Grounded Theory ( $2^{\text {nd }}$ ed). London: SAGE Publications.

Streeten, Paul. 1984. "Basic Needs: Some Unsettled Questions." World Development 12(9): 973 978.

Streeten, Paul, and Shahid Javed Burki. 1978. "Basic Needs: Some Issues.” World Development 6(3): 411-421.

Suh, Eunyoung, Sarah Kagan, and Neville Strumpf. 2009. "Cultural Competence in Qualitative Interview Methods h with Asian Immigrants." Journal of Transcultural Nursing 20(2): 194-201. doi.:10.1177/1043659608330059.

Thornton, Thomas F. 2001. "Subsistence in Northern Communities: Lessons from Alaska." The Northern Review 23: 82-102.

http://journals.sfu.ca/nr/index.php/nr/article/viewFile/167/165.

Tjoe, Yenny. 2013. "Decentralization and Poverty Reduction in Indonesia: The Case of East Nusa Tenggara (NTT)." In The Asian Century, Sustainable Growth and Climate Change: Responsible Futures Matter, edited by Moazzem Hossain, Tapan Sarker and Malcolm McIntosh, 178-199. Cheltenham: Edward Elgar Publishing.

United Nations Environment Programme (UNEP). 1992. Status of Desertification and Implementation of the United Nations Plan of Action to Combat Desertification. Nairobi: United Nations Environment Programme.

Wharton, Clifton R., Jr. 1969. Subsistence Agriculture and Economic Development. New Brunswick, NJ: Transaction Publishers. 
Wirajuda, Hassan. 1999. "Pribumi dan Otonomi Dalam Mengatur Urusan Sendiri (Indigenous People Internal Self-Determination)." In Hak Asasi Manusia, Tanggung Jawab Negara, Peran Institusi Nasional dan Masyarakat (Human Rights, State Responsibility, Role of National and Public Institutions), edited by Sugeng Bahagijo and Asmara Nababan, 126-127. Jakarta: Komnas HAM (National Commission on Human Rights).

Yohanis, Bria. 2010. "Kebijakan Pemerintah Provinsi NTT di Bidang Pertambangan Mangan (NTT Provincial Government Policy in Manganese Mining)." Presentation at the Seminar Sehari: Potret Masa Depan Industri Pertambangan Mangan di NTT (One Day Seminar: Portrait of the Future of Manganese Mining Industry in NTT), Universitas Nusa Cendana, Kupang City, Indonesia, November 20, 2010.

\section{ABOUT THE AUTHOR}

Yenny Tjoe: Ph.D. Candidate at Griffith University, Griffith Business School, Department of International Business and Asian Studies, Brisbane, Queensland, Australia. Email address: y.tjoe@griffith.edu.au 